\title{
Teatro, televisión, cultura y otras manzanas (con o sin gusano) en la misma cesta
}

\author{
Juan Guerrero Zamora
}

\begin{abstract}
Abrigo la sospecha de que las personas sensatas que se encontrasen entre los asistentes a las jornadas desarrolladas en Melilla sobre televisión y cultura, hubieron de concluir en que las definiciones que se proponen sobre ambas especies son más bien confusas y como tirando de castaño a oscuro. De la primera, porque es niña - y los niños son el objeto menos definible de esta tierra-; de la segunda porque, si ni sus filósofos se conciertan respecto a su semántica propia, ¿cómo habrían de concertarse sus simples acólitos, entre los que me cuento? Sin ánimo - que sería feo- de señalar, alguien dijo que el vaso que tenía ante sí era cultura; algún otro fantaseó sobre un presunto lenguaje propio de la televisión; y un último - con lo que echo mano a la tercera manzana de las varias que contiene mi cesta de hoy - amuralló el concepto teatro con infranqueables y prístinas paredes vigiladas por severísimos vestales. Por supuesto que -como dijo Marco Antonio de los asesinos de César- todos eran hombres honrados: los aludidos y los demás ponentes, entre ellos yo que - no faltaría mástambién reivindico mi derecho a asesinar a César. Pero desarrollemos por partes esta fábula - fábula y signo, sí, añorado Salinas- de las tres manzanas.
\end{abstract}

\section{Cultura}

Antes -en ese antes tan alienado como entranable que poseemos quienes ya hemos traspuesto demasiadas esquinas-, la palabra cultura se refería al, conocimiento o saber, consistía en riqueza humanística implicando toda una escala de valores, se proponía sinónima del intelecto apasionado que dijo Pirandello, y significaba algo preciso y, por muchas que fueren sus matizaciones, sencillo. Claro que la filosofía de la cultura abordaba el tema más complejamente, pero, especulando en ámbito específico $-y$, para muchos, esotérico, por no decir críptico-, no hacía daño a nadie. Lo malo es que la especie saltó a la calle y que, allí, engullida por las informaciones sub o seudoculturales de los mass-media, se convirtió en un monstruoso mutante. La calle estaba infestada -el saber de oídas infesta, no forma- por los miasmas de disciplinas en sí mismas reveladoras y respetables como la semiología - y no cito otras por no extender el discurso-, redescubierta 0 , digamos, divulgada por el estructuralismo. $Y$, ciertamente, semiológicamente todo es cultura en cuanto que todo es signo. Pero lo que, en el raciocinio propio de esta ciencia filosófica es verdad en su mesura y con- 
creción, resultó en la práctica de la calle mera hipertrofia, superabundancia de significados embutidos en un significante -esa palabra cultura - a punto de reventar. $Y$ ha reventado. No saben los estructuralistas la que armaron cuando se les ocurrió pergeñar, por ejemplo, su teoría de una cultura de la moda. Las damas de la alta sociedad ya no se visten: hacen cultura. Y como la cultura - esa- es, como todo el mundo sabe, preocupación básica de los políticos, cuando éstos convocan al pueblo a una merendola con chotis, sevillanas, tortilla y ozonopino, to que hacen en realidad es incitarlo a manifestarse culturalmente. Lo que el pueblo come, en tal caso, no es tortilla: es cultura. Su manjar preferido, evidentemente. $Y$ así.

Cierto que un vaso, por su materia y forma, constituye un signo de una determinada cultura -aunque, en el caso antes aludido, no sea más que una triste cultura del plástico-, pero ¿hace cultura quien se lo bebe $\mathrm{y}$, en caso afirmativo, quien se lo bebiera una y otra vez, ansiosamente, habria alcanzado la calificación de hombre cultísimo? Nadie se aventuraría a tan pintoresca afirmación. Pero, entonces, ¿por qué se habla de una cultura del fútbol? ¿Por qué los homosexuales y —sin ánimo de comparar- las prostitutas reivindican sus propios espacios culturales? Caligula podrá empeñarse, si quiere, en nombrar cónsul a su caballo, pero su caballo seguirá siendo un caballo. Y no hay que darle vueltas.

La problemática que se implica en tal estado de confusión es tan enmarañada que, si hemos de atenemos a los límties de un artículo, no cabe sino enfocarla en clave de humor. No obstante, es seria. Y estremecedora. Supone la diagnosis de una civilización que decae y que, como siempre ha ocurrido en estos trances, acelera su decadencia en progresión geométrica. Dije que el significante cultura ha reventado. No. Aún no lo ha hecho. Ni lo hará mientras exista alguien que se niegue a equiparar a $\mathrm{D}$. Ramón Menéndez Pidal con un futbolista en cuantos agentes culturales. Reventará cuando reviente el átomo. Porque no sólo es el átomo lo que hemos fisionado, sino todos los principios e incluso la posible objetividad de la verdad. Ahora sólo nos queda esperar a que se produzca el punto de fusión - que es el de confusión- necesario.

Como último matiz de estas digresiones -que podrian mantenerse interminablemente - precisemos, porque conviene a lo que ha de seguir, cómo la semiología -acientífica, entendida por cada uno pro domo sua- ha devorado, con el concepto de la cultura, la sustantividad misma de la estética. Hace años, cierto político cultural -y no han cambiado las cosas - nos postulaba que lo importante era promocionar el teatro sin discriminar -otra palabra abusada - calidades. A esto -que, obviamente, es idolatría de la cantidad, o sea el culto propio de una civilización masificada urgüía yo que lo importante es promocionar el buen teatro. Mi postura era estética; la suya, sin saberlo, semiológica en cuanto que toda obra teatral $-\mathrm{y}$ de cualquier otro génerocontiene signos, es decir: significa y es, por ello, digna de algún - por mínimo que sea- aprecio. Sólo que, si este aprecio gravita en uno de los platillos de la balanza, en el otro pesa el desprecio, la infusión desorientadora o degradadora de la que son capaces aquellos signos mínimamente apreciables y estéticamente descalificados. Dicho de otro modo: lo que es válido en un orden puede no serlo en otro, como se ve con el concepto democracia cuya incuestionable cualificación político-social se descabala en cuanto pretendemos implantarla en un orden óntico — serán iguales los votos, pero no los hombres-. 
Y ya que el término democracia salió a cuento, convendrá indicar que su actual inflación —o sea el modo, no pocas veces impertinente o improcedente, en que se aplica a troche y moche- incide muy especialmente en esa indefinición del concepto cultura de la que vengo hablando. El necio está siempre tentado a reducirlo todo -como dijo Isaías - al nivel del asolamiento que, claro, es el suyo. Así, según los fueros que le concede su particular - y falso - sentido de la democracia, embiste contra la cultura entendida como privilegio de élites, pretende hacerla bien común pero, eso sí, como gracia infusa, no como grados de conocimiento entrafiado $y$, al no caerle del cielo lo que demanda, opta por expropiar el concepto. Desmitifiquemos la cultura, clama. Ay, clamo yo en mi propio desierto, de las civilizaciones cuando se tornan incapaces de convivir con sus mitos saludables -con sus arquetipos polisemánticos-: porque terminarán creando otros, ídolos falsos, becerros de oro - como el busto potente de Diana Dors vaciado en dicho metal y expuesto en América para pasmo de gentes-, signos icónicos desprovistos de contenido. $Y$ el necio sigue y sigue manipulando los vocablos en boga que conoce de oidas - campanadas que ignora de donde proceden-, y continúa con su ciego trasvase semántico, empleando palabras en órdenes que no le son propios, como libertad -ontológicamente vacua-, humano -ilícita si se la supone salvoconducto ético-, derechos humanos -a fortiori discriminables según la conducta-y, como vengo diciendo, cultura.

Decía Romain Rolland que, si deseamos tener un teatro popular, habremos dc comenzar por tener un pueblo. Pero ésta, pueblo, es hoy una de las palabras más semánticamente ambiguas, de donde el fracaso de todos los intentos de popularización del arte dramático, inclusive el emprendido por Mao o, mejor dicho, por su mujer en el marco de la revolución cultural china. Y es que el pueblo, al urbanizarse, se proletariza y, ya en este grado de la escala, empieza a perder su disponibilidad para admirar y/o aprender. Excuso decir lo que sucede cuando, remontando la escala, el proletario accede a un status social que se supone autosuficiente. Le basta ya con lo que sabe aunque su saber provenga de la prensa del corazón o de los informativos televisiblesy se infatúa. Jamás entenderá a Don Quijote, pero su fatuidad tampoco es, como en Sancho, la del refranero, porque el refranero en definitiva es cultura de la ticrra -no de oficina o taller- y la tierra es pueblo. E, infatuándose, se torna agresivo. ¿No habéis padecido nunca su reticencia cuando, al ser rectificados por vosotros, os tildan de cultos? Proceden desde un complejo - su carencia- y, consecuentemente, atacan. Entre las raíces históricamente consecuentes de las contraculturas se da, espúrea, ésa psicológicamente patológica. Su razón es la del mendigo que muerde la mano del que le ayuda.

Como los caminos para llegar a Roma son múltiples, tanto el citado nivel del asolamiento - para que todos, por fuero democrático, seamos culturalmente igualescomo la confusión ya dicha entre estética y semiología llevan al mismo puerto: la devaluación. De otro modo expresado, todo ello se practica en mengua de la axiología, con un soberano desprecio hacia la teoría y realidad de los valores. Que, por supuesto, estorban a la proclamada igualdad. Desde la inmensa minoría de Juan Ramón Jiménez hasta la inmensa mayoría de Blas de Otero hay, en el terreno de la cultura - y de la estética y su sensibilidad - un camino largo. Triste. El de una mixtificación por la cual se etiqueta como élite - ihe de aclarar que despectivamente? - a los depositarios del 
merecimiento. $Y$-lo que no obsta a la insoslayable igualdad de oportunidades ni a la necesaria universalidad de la docencia - siempre fueron, son y serán estos depositarios quienes. ensamblen el arco de la cultura, quienes dirijan a los pueblos, quienes dinamicen la Historia. Todo lo demás o es fraude o es demagogia.

Cabría affadir que no sólo el necio, el carente o el iletrado propende a esa confusión algunos de cuyos fenómenos voy exponiendo - con la ansiedad de acercarme al ser de los mismos-; también el arqueólogo cae en considerar obra de arte lo que no es más que pieza de arqueología, y el bibliófilo en apreciar como obra literaria lo que no pasa de ejemplar raro o curioso. Tanto monta. Son deformaciones profesionales. Y, entre ellas, la más temible: la que - ya estamos con MacLuhan, que distaba mucho de defender el aserto - afirma que el medio - es decir la televisión- es per se el mensaje. Qué monstruosidad. Equivale no a creer en la indisoluble unidad - yo diría simbiosis- entre forma y fondo, sino a postular que la obra es el libro, el celuloide, el bronce, la piedra, el piano o el lienzo.

Insisto aun con reiteración: no me refiero a la filosofía de la cultura -ni Jasinowski ni siquiera Scheler o Hegel tienen vela en este entierro, pues de entierro se trata-y claro es que soy capaz, como cualquiera, de hablar de una cultura humana $-y$ hasta animal-, de una cultura occidental $\mathbf{u}$ oriental, y de culturas nacionales, regionales etc. En tales extensos radios de acepción, la cultura es un conjunto de fenómenos distintivos, o sea los modos diferenciales de un ámbito mayor o menor. Lo que analizo es la acepción del vocablo a ras del suelo, donde por todo lo dicho, por otras muchas razones que olvido y porque las fronteras son cada día menos nítidas ¿no dijo Ezra Pound que la poesía actual es inconcebible sin la economía?-, se ha desbordado su semántica propia. Y ya se sabe: cuando un río se desborda, deja de ser río - se sale de madre, se desmadra y, consiguientemente, degenera - para convertirse en una catástrofe. Es una forma como cualquier otra de romperse el propio bautismo.

En fin que, si es cierto, como decía Ortega, que la cultura es como un movimiento natatorio que nos salva de hundirnos, cualquiera diría que todos nos estamos hundiendo y que tratamos de impedirlo deseando, por puro miedo, que todo sea cultura.

\section{Televisión}

Esta manzana es una gusanera. Y de ahí que, cuando mi amigo José Luis Fernández de la Torre osó organizar en mi tierra las jomadas que intrépidamente relacionaban televisión y cultura, se ganase el útulo al menos de temerario.

Aunque no sea fácil deslindar la televisión en abstracto de la que en concreto conocemos, haremos el esfuerzo de intentarlo. No es preciso advertir que es a aquélla, a la conceptuada en abstracto, a la que aludo si digo que la televisión es el vehículo difusor de cultura más poderoso que se haya inventado, lo cual no implica que cancele la galaxia Gutemberg —o quiera Dios, por lo que luego se verá, que no lo implique-. Ya nos son familiares su expansión y penetración, su fuerza —determinante en razón inversa a la cultura del telespectador - y su hechizo hipnótico - paradójicamente capaz de imponer la regla del silencio-. Pero aún estamos lejos de aquilatar sus inmediatas y ya previsibles consecuencias - no digamos las mediatas y casi inimaginables-, cuan- 
do nuestras opciones no se limiten a uno o varios canales nacionales y queden ampliadas al sustento $\longrightarrow$ pasto, según - que nos suministren por cable o por satélite borrando, ahora sí definitivamente, las fronteras en este mundo pecador, sin más obstáculos que las diferencias idiomáticas - lo que es problema de cada cual一. ¿Qué sucederá entonces? ¿Habremos conseguido el estado ecuménico $o$, lo que es más probable, ilimitándonos de algún modo, quedaremos indefinidos? ¿Qué es del árbol que, por crecer más arriba de lo que su parcela le consentía, se vence desarraigándose? ¿No se seca? ¿No se convierte en espectro, como dice la Cábala, quien juega con espectros? Y puesto que sólo un incurable optimista podría prever un perfecto equilibrio entre las fuerzas de esta fanatizada geografía terrestre, ino iremos a balancearnos en el movimiento pendular de las colonizaciones, según preponderen tal o cual potencia, signo político e incluso esquemas mentales en boga? Me lo temo. En alguna otra circunstancia he fabulado un estremecedor futuro. Imaginemos que todas las televisiones de este mundo, sine die, mostraran en primer plano el momento en que tomamos café $\mathrm{y}$, en plano general, el de cualquier asesinato - valga de ejemplo-. Llegaría el momento - no sé cuándo, quizá dentro de mil o de un millón de años, qué más da - en que la mente habría sido modificada de manera que estimariamos prevalente el acto de tomar café y desdeñaríamos como algo sin importancia -borrosamente lejano- el de asesinar. No es delirio. Sería éste, o podría serlo, un mínimo exponente de lo que cabría prever como toda una política de avasallamiento, invasión y depauperación axiológica, para cuya puesta en marcha bastaría la suficiente presión de determinados grupos, llámense económicos, políticos, de clase y hasta publicitarios. Recuerdo, acerca de esta última referencia, que quienes fundamos en España la televisión, rechazamos de plano y con absoluto respaldo la pretensión de las agencias publicitarias que, merodeando como abejas la presunta miel, solicitaban la inserción de sus anuncios en los momentos más expectantes de cada obra. Los anuncios se agrupaban antes y después, nunca entre el contexto audiovisual. Pero, a no tardar, la ley quedó hecha añicos y, de concesión en concesión, la publicidad fue ganando terreno, fragmentó las obras, trizó la emoción y la tensión, proliferó como una monstruosa excrecencia que de algún modo atenta contra el sentido y obviamente contra el ritmo sin cuya percepción no cabe el gusto de la obra de arte-. Poderoso caballero es don dinero, claro. Y si esta aberración pudo imponerse y es hoy moneda corriente en todo el mundo sólo por presión económica y dictado de agentes publicitarios, ¿qué no serían capaces de imponer los gobiernos al más vano de sus escaparates, a la más deslumbrante de sus vitrinas, al más masivo de sus embajadores, al más intruso de sus espías, al más seductor de sus juguetes?

La televisión, se produzca donde se produzca, se manifiesta siempre -con excepciones que no son sino coartadas- uncida por un yugo múltiple: a) hegemónica entre los mass-media, es, como dije, la tribuna más codiciada por los políticos y, por tanto, el modo de exhibición preferido para y acosado por el poder y quienes lo detentan. Los gobernantes son sus divos; los políticos, sus vedetles. $Y$ quienes, como yo, hemos tenido la desgracia de proponernos sus (con perdón) artistas, más pronto o más tarde quedamos reducidos al papel de bufones en tan procelosa corte. b) Lo que sustantiva al medio es su capacidad de ofrecer audiovisualmente el acontecimiento en el mismo momento en que se produce; lo que se llama transmisión en directo. De ahí que, no sin 
cierta legitimidad, los informadores se hayan ido apoderando de él, creando en su interior un reino de taifas - nótese con qué prepotencia y espíritu de casta se autoetiquetan en TVE: Es un programa de los Servicios Informativos- con, a veces, innegable profesionalidad, criterios objetivos, sentido plástico y otras virtudes, pero también, en no pocas ocasiones, imponiéndonos el desaguisado estético de núbiles doncellas recitativas - tituladas presentadoras - que robotizan nerviosas su prosodia; de reporteros que, presuntos valentinos, se creen en el derecho de situar ante la cámara la personal locución de un talento - como el valor al soldado, supuesto- cuyo sitio está detrás; de insignes expertos, cuya eclosión nadie supo nunca cuándo, dónde y cómo se produjo, capaces de sustraerle el protagonismo al mismísimo diablo; de babélicos dialectizadores del castellano que, por aquello del Estado de las Autonomías, nos perforan los oídos con acentos lícitos y hasta bellos en sí mismos pero caóticos en su conjunción; y -con lo que me detengo al apercibirme de que involuntariamente he venido a parar a la televisión española en concreto- de agentes subliminales o liminales de intoxicación. c) El número determina al medio. Y el número, generalmente, es enemigo. La TV dirige a un público masivo que en razón inversa a la actividad de su cerebro exige más o menos. El problema, en la consiguiente situación de dependencia, no estriba en cómo contentar a tan inconmesurable y heterogénea masa, sino en que, como mandan los más y no los mejores, una televisión que se propusiera auténticamente cultural - por moderada que fuese su estrategia - acabaría espoleando la indignación de aquellos que, antes y ahora, esgrimen su derecho al pan y circo. Para colmo, la evaluación se practica desde los llamados paneles de audiencia, las estadísticas, el marketing y demás lindezas hoy pasmosamente establecidas como criterios de valores, y el resultado, claro es - salvo excepciones por contaminatio-, apoya comunmente lo mediocre: esos seriales no río sino catarata - y nunca mejor empleado el símil dado su carácter lacrimoso- y tantos otros envasados de la misma ralea. Pero, además, el número sigue hostigando al medio desde otros muchos flancos: desde el horario ¿cómo sería posible una creatividad aun medianamente inteligente para tantas horas de emisión?-, desde la proliferación de emisoras - ¿qué cuadros capacitados serían precisos para mantenerlas siquiera a un nivel mínimo de dignidad? - y, por fin, desde los ingentes costos que la bestia devora y que, naturalmente, reclaman su satisfacción y su beneficio a costa de la poco rentable calidad.

Pese a todo, no, no existen razones - ni cuatro (las aducidas por cierto autor norteamericano) ni mil- que aconsejen suprimir la televisión. En nuestra galaxia electrónica, es su voz propia. Clausurar esta voz equivaldría a pretender clausurar el estadio histórico que nos ha tocado vivir. Sólo que ese estadio es malthusiano, con todo lo que comporta la masificación. ( $Y$ hasta es posible que, así como la jirafa desarrollo su cuello alargándolo por tener que alcanzar su alimento en la copa de los árboles, nuestra civilización malthusiana haya desarrollado lo electrónico como un órgano inmanente a su propia naturaleza y sus necesidades). Pero no nos desviemos. El fenómeno de la televisión es irreversible y, si se quiere, irremediable. Está en nuestras manos, como el átomo. Todo lo que nos cabe es ver cómo podemos domenarlo antes de que nos devore -de su insaciabilidad ya tenemos sobradas pruebas- y nos reduzca, aniquilándonos al ángel que debe trascendernos, a lo demasiado humano. Y para esta labor de doma la primera, imperiosa premisa es saber en qué consiste lo que hemos de domar. Intentaré 
definirlo sin que me importe incurrir para muchos en lo obvio.

No, niego tajantemente que la televisión sea en sí misma el mensaje. Es, sí, ni más ni menos, un medio técnico que dispone diferencialmente, por un lado, de su sincronía con el hecho que muestra y, por otro, de un camino de ondas intangible por el que puede saltarse el espacio. De algún modo, es un taumaturgo que puede trocar lo mediato en inmediato -aunque, por otra parte, también es cierto que torna lo inmediato en mediato bien porque lo distancia (en lo que algo tienen que ver el tamaño y planitud de las pantallas), bien porque a fortiori convierte lo vivo en pintado-. Y es un crisol que imprime una forma, fundiéndolos, a los materiales que se le suministran o que difunde telespacialmente obras (de todo tipo) ya hechas y fijadas. Jamás debe ser identificada con el alquimista. Los alquimistas son los otros, sus agentes, sus proveedores, sus ahora sí- mensajes, en definitiva: sus contenidos. $Y$ esos alquimistas serán quienes, creadores, trasmuten el plomo en oro -es decir, como lo sabe el ocultismo, en espíritu- o, estériles, nos lo devuelvan en su ser de plomo astutamente envuelto en oropel. Aunque lo digan no pocos profesores de comunicación, la televisión, teóricamente hablando, no es la culpable de los estereotipos que esparce, de la parcelación dicotómica de la realidad, de la evaluación maniquea o de la suplantación de la experiencia por un sucedáneo. Su consustancial inocencia proviene de su falta de voluntad. La voluntad se la pone el hombre, tanto su agente como su paciente.

¿Dónde está, pues, el peligro? En uno genérico de nuestra época: que hemos dado un pasmoso salto en el campo técnico, pero, como la filosofía -que es el ánimo (alma) real de todo progreso- se nos rezagó, el salto fue dado en el vacío. Por mucho que, en las jornadas en cuestión, los funcionarios de nuestra televisión, poniéndose el parche antes de ser heridos, afirmasen que no hay que exagerar respecto a la influencia del medio y a su poder suasorio o disuasorio, la televisión es una espada. Pero está en manos de un niño. Por no decir de un necio.

Hoy por hoy resulta como la Górgona llamada Medusa, cuyos cabellos eran serpientes y que podía petrificar a quien la miraba. Pero no olvidemos que, cuando Perseo le cortó la cabeza, su sangre y sus cabellos se trasmutaron en sartas de corales bellísimos. Lo que nos hace falta, pues, es un Perseo. O muchos. Y ya que hemos echado mano de la mitología, esa universal auxiliadora, apliquemos al controvertido invento un viejo mito: el de Pandora, la perfecta estatua animada por Hefesto, a la que cada dios dotó con su don propio -Afrodita, con la belleza; Hermes, con la palabra; Atenea, con el talento-, enviándola luego Zeus a la tierra portadora de una misteriosa caja. Algo me perturba y es que me envío fuera hecho con intenciones vindicantes respecto a Prometeo, es decir respecto a la cultura misma (el fuego robado por aquél a los cielos). Y no menor inquietud me produce el hecho de que Prometeo -el próvido, el previsor, el lúcido (todo ello según su nombre etimológicacamente indica)-, en vez de gozarse con la superdotada aunque no fuera más que para probarnos que la cultura no es frígida, la cediera al bobo, irreflexivo, miope, epilogal y casi descerebrado - todo ello también según su nombre etimológicamente indica- Epimeteo. ¿Qué subconsciente precautorio le indujo a tal cesión? Pero no nos hagamos demasiadas preguntas en un terreno que, en cuanto mitológico, ya sabemos dominado por la fatalidad. Tenía que ser así, y basta. $Y$ del mismo modo tenía que suceder que fuera Epimeteo quien, curiosillo, abriera la dichosa caja. Los exégetas establecerán inmediatamente 
una igualdad, por aquello del sincretismo de las creencias: gozar a Pandora, como a Eva, equivalía a abrir su caja o, dicho menos pornográfica y más teológicamente, pecar. Pero yo me opongo, primero porque, si la caja de Pandora no era caja sino símbolo ¿tengo que decir de qué? - no entiendo a Prometeo a no ser que fuese homosexual, me solidarizo plenamente con la curiosidad de Epimeteo, y no hallo explicación para el contenido, todos los males, que la caja celaba y que, libertos, se esparcieron por la tierra. No es posible que la deliciosa entrepiema de Pandora, nada menos que cincelada por Afrodita, contuviese tanta calamidad pública. No. Lo que sucedió realmente fue que Prometeo/Cultura receló del nuevo y fascinante invento -Pandora/Televisión-, como recelaron los intelectuales ante la aparición de la radio $\mathrm{y}$, luego, de su vidente hermana mayor; que, en consecuencia, no hizo lo que debiera: apropiársela como un gitano legítimo desdeñando lo que pudiera o no pudiera encerrar la caja - ino serían las últimas consecuencias presuntas de todo nuestro progreso?-; y que, ay, puso la bella espada en manos de un bobo. Lo dicho: era el sino. ¿Y no será ése el sino fatal de la televisión, hagan lo que hagan los nuevos Prometeos, aunque se aventuren en el goce del que su arquetipo se abstuvo? Recordemos consolatoriamente que, cuando todos los males emergieron de la caja, en el fondo de ésta sólo quedó una cosa: la esperanza. Y digo yo: la esperanza de que en un futuro, al alba de la sabiduría, Pandora ...

Reconoced que, se no é vero, é ben trovato, y sigamos adelante.

\section{Y teatro}

Aunque, al escribir este epigrafe, ya extraigo de mi cesta la tercera manzana y lo hago aprisa y corriendo para hurtarme a la tentación de aplicar las anteriores consideraciones a mi larga experiencia en una televisión precisa: la espafiola, he de advertir que medio millar de originales/adaptaciones/direcciones/realizaciones llevados a cabo en el medio, otro tanto en radio, no pocos montajes teatrales y miles de páginas escritas y publicadas sobre el teatro, creo que son credenciales suficientes para acreditarme imparcial respecto a todas y cada una de las técnicas existentes de dramatización. La TV está entre ellas -aparte sus otras funciones difusoras y aparte asimismo sus otras modulaciones (determinados reportajes, algunos collages icónicos, ciertos documentales intencionalmente arquitecturados) con entidad artística-. Para dramatizar, la TV se nutre de cuanto puede, pero básicamente de la novela, el relato $\mathrm{y}$, cómo no, el teatro, a los que imprime cuño propio. ¿Es decir, lenguaje propio?

Para contestar, aunque sumariamente, a este controvertido interrogante, comencemos por despejar todo cuanto no responda a los términos estrictos del binomio: teatro/televisión. Atengámonos a la traslación del uno a la otra. Nos apercibiremos, de entrada y con perdón de los puristas, que, si salimos de Pinto, entramos en Valdemoro; que el tránsito sólo se realizó entre las formas inherente a la técnica; que lo sustantivo sigue incólume. Lo sustantivo es el arte dramático. Dispuso secularmente de una residencia que, para entendernos, llamamos escena (abierta a la griega o cerrada a la italiana), y hoy aún busca descongestionarse más ocupando locales de toda índole e incluso la calle misma. Es una línea de evolución cuyo denominador común es la presencia viva del actor, la fluencia directa escenario/sala, su hic et nunc idéntico para el 
espectáculo y para la expectación. Como no siempre hay que fiarse de las etimologías o no tomárselas al pie de la letra - teatro proviene del verbo ver y drama equivale a acción-, antes y después de que Aristóteles codificara su preceptiva, el verbo fue el elemento hegemónico. La degeneración de esta primacía originó, como se sabe, una hipertrofia - verbalismo/sicologismo- contra la que muchos se alzaron, cada uno a su modo: desde Artaud y Jarry, pasando por los neoconvencionales franceses - Ionesco, Beckett-, hasta el happening, por sólo describir un panorama a vista de pájaro. En resumen, el teatro quiso ser más activo -incluso formularse mágicamente-, recuperar sus raíces rituales, operar hasta físicamente sobre el espectador $y$, ante el desgaste o la esclerosis de las palabras, hacer señas, lo que en definitiva no era sino acentuar más su sentido etimológico acción para ser vista. Como soy el primer promotor crítico de todas las vanguardias - perdón por esta nueva credencial一, nadie podrá tildarme de reaccionario si digo que el teatro en su encarnación occidental sigue arquitecturándose en torno a la palabra -aunque ya su elocución no se conciba sino en un marco espectacularmente conjugado, escenográficamente calculado, en el que se integran elementos de todas las artes y el cuerpo del actor no es sólo una boca dicente sino, como quería Appia, reloj para el tiempo y compás para el espacio- y que las experiencias nuevas -que acepto en su integridad como tales, no en su contestable consecución estéticaserán para teatro, pero no el teatro cuya consistencia precisa, por evolucionada que la sofiemos, ha consagrado el tiempo.

$Y$ he aqui que advino la radio. El teatro dispuso entonces de la posibilidad de su elocución a distancia, sólo que desencarnada - admitiendo que la voz no dé ya un grado de encarnación al verbo-. Era una forma nueva del arte dramático, como es obvio exclusivamente sonora que, en compensación de la ceguera nos imponía, nos regalaba otro modo de videncia -el que resulta de una imaginación o visión interior mejor estimuladas por el cálculo del ruído y la planificación de la palabra- y, en la práctica, otros dones que no dispongo de tiempo para seguir analizando.

$Y$ he aquí que advino la cinematografía. No contaba con las ondas; no era arte dramático a domicilio; su hic et nuc, su aquí y ahora, eran distintos para el espectáculo y para el espectador; pero, al igual que la radio; atomizaba definitivamente la unidad de lugar, podía alcanzar cotas de espectacularidad imposibles para el teatro, convertía en cinética la plástica y se imponía por los fueros de una dinamicidad siempre anhelada pero, en la corporeidad de la escena y entre sus límites, utópica.

La televisión llegó al fin, como la universal cosechera de todo lo cosechado y, además o para ello, montada en una carroza de privilegio: la electrónica. Fue insisto- la cuarta técnica de un mismo arte: el dramático. Esto es un axioma y, sin embargo, abundan las posturas radicalizadas que lo olvidan o lo niegan, con lo que si unos - los postores de la televisión-pretenden edificar su teoría, por lo demás importada del cine, sobre la afirmación de que una imagen vale más que mil palabras disparate que cualquier poeta podría desmontar pues sabe de sobra que, donde terminan las imágenes icónicas comienza el margen intangible de la realidad suprasensorial (o del misterio) sólo aprenhensible mediante otro tipo de imágenes; y obsérvese cómo ya el lenguaje vino a utilizar el mismo vocablo: imagen, para definir, con su poderosa y yo diria fatal intuición, otra forma de visión (visionaria, precisarían Dámaso y Bousoño) de mayor radio que la física-; si aquellos radicales estarían prontos a defender que la 
dramatización televisible responde más cabalmente, o con mayor riqueza, que el teatro al sentido etimológico de éste y del drama -recuérdese: acción para ser vista-; si estos paladines de la nueva técnica preconizan que es ella la forma teatral distintiva de nuestro tiempo, en tanto que el teatro propiamente dicho debe ser -0 será- relegado a estadios de cripta o cenáculos para iniciados; mientras estos parciales se fanatizan con el flamante juguete, los otros, los turiferarios del teatro propiamente dicho, caen en aquella vigilia de vestales que ya mencioné, hablan de teatro químicamente puro como si en nuestra época lo definitorio no fuese la impureza-, consideran el hecho teatral como un culto, casi misterio de Eleusis, algo intocable que las manos profanas de la televisión degradan, destape visceral que aquélla congela, sacralizando su credo y, paradójicamente, al mismo tiempo, ansiosos porque la televisión lo divulgue, eso sí, por la mera información o-como si la televisión hubiera de ser el escriba documental de sus obras- por la simple retransmisión. Los unos, en fin, postulan: el arte dramático televisible ha sustituído al teatro - el teatro ha muerto; viva en televisión-; los otros claman: la televisión es una ramera que prostituye al teatro - mastúrbese si quiere, pero que no ose cohabitar con la eximia pareja-. Unos y otros inciden en el mismo error: la existencia de un teatro televisible, con lo que están pensando en un híbrido de dos técnicas e ignorando que es el arte dramático el que puede ser o teatral o televisible, o sea una misma sustancia la que puede expresarse por dos vehículos distintos.

De qué modo un texto teatral puede ser trasvasado a televisión, resulta obvio si se parte desde aquella premisa. Rechazo de plano su retransmisión directa, a no ser que se busque la realización de un documento -documentar en imágenes una representación, a efectos testimoniales para el futuro o didácticos-. En el trasvase, el imperioso plano general de la escena se gradúa según una planificación que acerca, aleja, selecciona un punto de vista y fragmenta el cuadro según las exigencias del contenido, la acción y el ritmo, o sea según las necesidades expresivas de los significados. Este subrayado semántico es en la escena precario: cuenta sólo con el juego de las luces, el movimiento o posición del actor y otrós métodos que, todos, están sujetos a un plano general, puesto que la escena está en sí misma en plano general respecto a la visión del espectador. Cierto que la planificación televisual $-y$, claro, la cinematográfica-impone al público una evaluación, de cuyo acierto o desacierto depende el valor estético de la obra. Cierto también que el teatro es inmediato - algunos dicen caliente- y la televisión mediata - dicen que fría - y que en ésta, desde luego, el espectador no tiene acceso a la fluencia física del actor o del espectáculo, lo cual hace difícilmente trasvasables determinadas formas actuales del teatro, pero esto sería largo de ejemplificar. Y es igualmente cierto que la obra dramática televisible tiende a confundirse, así planificada, con la cinematográfica, quedando en entredicho su presunto lenguaje propio. Este lenguaje -digámoslo de una vez- es ecléctico, vocablo que sé cuánto rechazo produce sobre todo en sectores juvenilmente polarizados. Sus diferencias con el teatro han sido al menos aludidas, pero esas mismas diferencias son las que la asimilan al cine. ¿Entonces?

Se ha producido, creo que irreversiblemente, una falta de idoneidad entre la televisión y sus instrumentos. Superada la fase de la emisión en directo dados sus riesgos de error 0 , incidentes, de involuntarias emergencias, me inclina a pensar que el instrumen- 
to idóneo de aquélla es el magnetoscopio y sus cámaras correspondientes. Por una razón muy simple: porque a lo electrónico conviene sin duda lo electrónico. Cuando una película es emitida se produce una conversión de un sistema en otro. Si la película fue realizada para o con destino a la televisión, una de dos: o se atuvo a la gradación cinematográfica $-y$ ya veremos por qué digo gradación-, con lo que impone a la gradación propia del lenguaje televisual otra distinta; o respeta ésta, sacrificando la idónea del celuloide y su cámara pertinente. Si la película no fue realizada para la televisión —existía ya en la filmoteca universal-, el resultado de su emisión nunca es optimo: la patalla TV reduce sus imágenes, o las cercena por los márgenes -al haber sido rodada aquélla en formatos superiores a los $35 \mathrm{~mm}$.-; no soporta determinadas intensidades de lo oscuro - la noche, para entendernos, en TV siempre es más clara que en el cine - que se emiten impenetrables; sus planos generales enmudecen entiéndaseme - al trocarse en mocroscópicos; y podríamos seguir citando lo que cualquier observador sensible ha notado infinidad de veces. En consecuencia, lo que procede es el uso de los sistemas de grabación electrónica, que son justamente los que definen -y toda autodefinición implica el reconocimiento de los propios límitescomo televisual a la obra dramática. No es cosa de hacer exhaustiva enumeración de las características de tal sistema, pero hablaré de algunas que el profano puede desconocer. Se rueda -en cine - plano a plano - aunque el plano pueda ser secuencial-; se graba - en TV - por conjuntos de planos que constituyen secuencia o amplio fragmento de la obra - ventaja que al realizador otorga el hacer su tarea con varias, generalmente cuatro, cámaras que preparan cuatro imágenes distintas, visibles en otros tantos monitores, seleccionables y permutables mediante la mesa de mezcla-. Esto supone, de un lado, ahorro en el tiempo de la realización con su consiguiente economía; de otro más importante - por ser estético-, que el actor pueda concatenar con más amplitud los sentimientos que ha de expresar, que no haya de fragmentar su lenguaje expresivo tanto como ha de hacerlo en el cine - con el fatigoso esfuerzo de reanudar una y otra vez su situación, si no quiere caer en la incoherencia-, y, en fin, una espontaneidad mayor que acerca su trabajo al que efectúa en la escena teatral. De esta misma ventaja se beneficia el director/realizador, quien, por otra parte, electrónicamente, puede en cada instante modificar la calidad del color y -no sujeto a las sorpresas muchas veces ingratas de los resultados sólo comprobables tras el proceso de revelado y positivado- sabe siempre - gracias a la electrónica, sus monitores le están dando los resultados últimos, si no del montaje, que de ése sí depende a posteriori aunque apriori lo tenga necesariamente previsto, al menos de la imagen qué grado de consecución icónica, histriónica y plástica tiene su plano. El proceso, pues, en TV se concentra, suprime intermediarios -el laboratorio-y neutraliza voluntades que pueden ser interferentes - la del operador que, en un travaelling, dice haber llegado y no llega a la cercanía o lejanía exigidas por el director, quien sólo descubre lo ocurrido cuando el laboratorio le entrega el copión-. Claro que la calidad luminotécnica -al atender ésta a un conjunto de planos- tropieza con dificultades -en buena parte subsanables- que imposibilitan la extrema perfección a la que puede acceder el cine; pero, en cambio, la profundidad focal de la cámara de video es muy superior y capaz sin mayores requisitos de mantener simultáneamente a foco objetos separados desde el primer al último plano - aquel alarde que Orson Welles pudo efectuar en La sombra de 
una duda a costa de una iluminación rabiosa que le permitiese cerrar al máximo su diafragma-. La versatilidad, en fin, de la cámara electrónica ha llegado a tal punto que uno se pregunta si la cinematográfica sólo la sostienen ya los intereses industriales aunque también es cierto que el soporte cinta es más caducible que el soporte celuloide-.

Por último y en razón inversa al tamaño de la propia pantalla, la obra televisual y la cinematográfica dosifican diversamente sus planos acentuándolos más la primera mayor número de primeros planos- y permitiéndose la segunda más frecuentes alejamientos: es lo que llamaba sus gradaciones diferenciales.

Etcaetera, etcaetera.

¿Basta lo dicho para trabar un lenguaje? No lo sé. Creo que el sincretismo propio de la televisión ya concreta suficientemente su identidad, pero no sé si es lícito hablar de lenguaje, sobre todo cuando presencio la borrachera"electrónica - de efectos que ya vienen realizados en tabletas de fábrica - que muchos tienen por tal -medítese en el frecuente delirio de los llamados videoclips-, sabiendo como sé qué pocos realizadores están dotados para una utilización gratificante de las cámaras electrónicas - sin reflejos que les faculten a su simultaneidad, sin la celeridad de criterio precisa para la urgente selección, sin la imaginación aventurada que les lleve (lo tópico es la disposición de las cámaras en abanico frente a la escena o lugar de acción) a calcular campos y contracampos, y otras muchas cosas-, y asistiendo al cajón de sastre en que toda televisión termina por convertirse. No lo sé, pero, si a la realidad hemos de atenernos - aunque sea una realidad degenerada-, tampoco importa mucho.

\section{El carro de las manzanas}

Como carezco de tiempo y paciencia para extraer las muchas manzanas que me restan, le tomaré a Bernard Shaw prestado el tútulo, para volcarlo. ¿Por qué no echarlo todo a rodar, si ya se encarga nuestra época de hacerlo?

Con respeto, con muchísimo respeto, como el alcalde calderoniano, hacia conspicuos profesores, aficionados en posesión infusa de la verdad y demás especies Zorrilla diría- exóticas de cuantas pueblan nuestros predios, no tengo otro remedio que salirme de la teoría y entrar en la práctica y, por tanto, en mi experiencia de la televisión que mejor conozco: la española.

Milan Kundera, en su admirable novela La insoportable levedad de! ser, escribe: El kitsch provoca dos lágrimas de emoción, una inmediatamente después de la otra. La primera lágrima dice: ¡Qué hermoso, los niños corren por el césped! La segunda lágrima dice: iQué hermoso es estar emocionado junto con toda la humanidad al ver a los niños corriendo por el césped! Es la segunda lágrima la que convierte el kitsch en kitsch. Y anteriormente: El sentimiento que despierta el kitsch debe poder ser compartido por gran cantidad de gente. Por eso el kitsch no puede basarse en una situación inhabitual, sino en imágenes básicas que deben grabarse en la memoria de la gente: la hija ingrata, el padre abandonado, los niños que corren en el césped, la patria traicionada, el recuerdo del primer amor ... Ahí está todo. La más precisa definición de lo que la televisión es - ¿de qué nos sirve reiterar sus, como diría Barrie (Dear Brutus) 
pudo-haber-sido?-, ahí está. Tras una larga lucha de algunos, muy pocos, venció lo que fatalmente tenía que vencer dada la esterilidad del resto, la progresiva invasión del medio por los enanos, la gratuidad de los planes de programación - salvo en lo que respecta a la sacrosanta política, TVE se rige en todo lo demás por un principio: Si sale con barbas San Antón y si no ...-, su exceso en personal de aluvión -que, naturalmente, termina por marcar a los auténticos profesionales con una base cultural-, su hipertrofia corporativista - no en uno sino en numerosos colectivos, según las especialidades, que cierran filas en cuanto se sienten amenazados defendiendo incluso lo indefendible- y, más o menos soterrafiamente, con más o menos excepciones, su rechazo hacia lo que suponga el ejercicio del intelecto por encima de un primario, elemental nivel analfabeto - ese segundo y, éste sí, culpable analfabetismo que Salinas veía y condenaba en quienes, sabiendo leer, no leen-. Cuando realicé mi serie Un mito llamado ...., el directivo de turno relegó su emisión a una hora impropia alegando que era una serie intelectual. Ante mi negativa a consentir que mi Fuenteovejuna fuera amputada, otro directivo se espantó -iPero es que ha mostrado la insurrección de un pueblo contra un tirano! -, como si Fuenteovejuna fuera otra cosa. Y así. Aquellos pocos, y yo entre ellos, podríamos aducir bastantes anécdotas coincidentes. En TVE prevaleció impuesto desde fuera - la audiencia- y desde dentro, el ideal estético de Un, dos, tres. Ese es su techo - desde luego preferible al que marcan un Goya pasado por agua o una Santa Teresa entre pucheros pero escasamente reflexiva y mucho menos mística: ya saben de qué hablo-; ésa, la medida cultural permisible; ésa, la capacidad de juego - $y$ también de autoescamio- oficialmente legalizada. $Y$ no es que me pronuncie contra aquel programa en particular; contra lo que me pronuncio es sobre el status que lo ha calificado de paradigmático y que, paulatina y paralelamente, fue sofocando toda manifestación de arte dramático propio. Las causas fueron muchas entre ellas, que los pequenios prometeos que osamos arrancarles a los dioses aunque no fuese más que una mínima candela, careciamos de un hígado que se autogenerase y pudiera resistir indefinidamente el picoteo no ya de las águilas sino de los insectos-, pero sobre todo una: que la televisión es la reina del kitsch y, conforme ha crecido, más irretenibles se han vuelto sus poderes para convertir cuanto toca, por quilates que posea, en kitsch. Apliquemos debidamente, como demostración, las palabras de Kundera. Pero si, continuando con el autor checo, pensamos que ninguno de nosotros es un superhombre como para poder escapar por completo al kitsch y que, por más que lo despreciemos, el kitsch forma parte del sino del hombre - sobre todo, añadiría yo, en las coordenadas de nuestro tiempo-, enternecidos llegaremos a la saludable conclusión de que todos, los asesinos y los defensores de César, somos hombres honrados. Con lo que podremos dormir tranquilos. 